\title{
Financial Vulnerability of Working Adults in Malaysia
}

\author{
Yiing Jia Loke ${ }^{1}$
}

\begin{abstract}
Given the high and rising household debt in Malaysia, the objective of this paper is to ascertain the characteristics of a financially vulnerable individual. Financial vulnerability is measured based on two indicators: the debt-to-income ratio and the level of emergency savings for income shock. The findings of this paper show that, in addition to socio-economic factors, other factors such as risk tolerance, savings portfolio, and individuals' objectives and subjective financial knowledge can significantly explain differences in the levels of individual financial vulnerability. Using ordered probit on primary data consisting of 854 working adults aged 18-60, it is found that gender, ethnicity, income, number of dependents, age and education can significantly explain differences in the levels of financial vulnerability. Furthermore, the findings highlight the importance of continuous efforts to provide financial education to improve personal financial management. The findings also confirm that risk takers are more likely to be financially vulnerable. However, individuals who diversify their savings channels to include stock and bond holdings instead of solely saving through bank deposits are less likely to be financially vulnerable.
\end{abstract}

KEY WORDS: $\quad$ Indebtedness, Financial fragility, Financial literacy, Emergency savings, Personal finance

JEL Classification: D14; D91

${ }^{1}$ Universiti Sains Malaysia - School of Social Sciences, Malaysia

\section{Introduction}

Household debt in Malaysia has been increasing rapidly in recent years, with the latest figure at RM940.4 billion (US\$234 billion) or 87.9\% of GDP in 2014 (Bank Negara Malaysia, 2015). This debt is the highest among its neighboring countries including Indonesia, Thailand, and Singapore. Furthermore, the debt service ratio of $44.2 \%$ indicates that approximately half of the households' monthly income is

Correspondence concerning this article should be addressed to: Yiing Jia Loke, School of Social Sciences Universiti Sains Malaysia Minden Penang 11800, Malaysia, E-mail: yjloke@usm.my used to service debt payments. As Malaysia strives to become a high-income nation, the country is grappling with the serious problem of a growing number of bankruptcy cases, particularly among the young. Meikeng (2014) from The Star reported that the number of bankruptcy cases in Malaysia has increased consistently from 13,238 cases in 2007 to 21,987 cases in 2013 . There was a significant $12 \%$ increase in bankruptcy cases from 2012 (19,575 cases) to 2013 (21,987 cases). Furthermore, Chow (2015) from Reuters also reported that there has been a significant increase in bankruptcies among those under 35 years old. According to the Department of Insolvency, a total of 24,953 people below the age of 35 had filed for bank- 
ruptcy since 2010 (Carvalho \& Hamdan, 2015). In fact, approximately $47 \%$ of those between $18-35$ years old are struggling financially and are living beyond their means, and 60 Malaysians are being declared bankrupt every day (Malaysian Digest, 2014).

High household debt can weaken private consumption spending particularly during an economic downturn. The problem can be exacerbated in a high interest environment as it will affect the debt repayment abilities of individuals and households. Furthermore, studies have found that a financial crisis that is preceded by large household debts will result in more severe downturns as highly indebted households and individuals will become credit unworthy as lenders tighten their loan offerings. For example, Mian and Sufi (2011) found that one of the key characteristics of the 2007/08 financial crisis in the United States was preceded by one of the largest increases in household debt in the country's history. Similarly, Chmelar (2013) also observed that household debt has a strong impact on the macroeconomic stability, the robustness of growth and the depth of the recessions. Furthermore, the high household debt to income ratio in Malaysia, which is 146 percent, is comparable to that of the U.S.A and the U.K. However, in contrast to high income nations and developed countries, the lower income levels in Malaysia raises the question of households' financial sustainability. Furthermore, while the United States and European countries share the same concern of high household debt in their respective countries, another point of concern in the issue of high household debt in Malaysia is the heterogeneity of its distribution and the direction of borrowing. Approximately $80 \%$ of household debt is by households earning higher than average income (greater than RM3,000 or US\$ 748), and 46.5\% is by households earning above RM5,000 (US\$1,247) per month. Furthermore, the leverage ratio for households earning less than RM3,000 (US\$748) ranges from 4.4 to a high of 9.6 times their annual income; many of these households obtained their loans from non-bank institutions that are outside the regulatory and supervisory purview of the central bank (Hussein, 2013). These statistics have attracted unwanted attention and raised concerns regarding the financial vulnerabilities of individuals and households in Malaysia.

Given the concerns about the increasing household debt, since 2010, the central bank of Malaysia has gradually implemented several micro-prudential measurements and introduced responsible financing guidelines for financial institutions. These new policies include changes such as raising the income eligibility requirements of credit card ownership, limiting the number of credit cards one can own, placing a ceiling on the credit limit of credit cards for cardholders with annual income less than RM36,000 (US\$8977), and reducing the loan tenure for various loans (Bank Negara Malaysia, 2011a; 2011b). With the implementation of these policies, household debt moderated slightly in 2014 but remains at a high level.

The slowdown in the economy, the higher cost of living and the implementation of the Goods Service Tax (GST) in Malaysia on 1 April 2015 may adversely affect financially vulnerable individuals. The Credit Counseling and Debt Management Agency (AKPK), which was established in 2006 to help financially distressed individuals manage their debt, has cited poor financial management as the main factor for financially troubled individuals as this explains 22.7 percent of those who are enrolled in their debt management program (Malaysian Digest, 2014). More than 700,000 individuals have sought help from AKPK since its establishment; in 2015 alone, 135,000 individuals have approached AKPK to help them solve their financial problems (Credit Counseling and Debt Management Agency, 2016). As such, based on the aforementioned issues, the objective of this paper is to ascertain the characteristics of financially vulnerable individuals. This information is vital to ensure that effective educational campaigns for responsible financial management target the financially vulnerable group, and relevant intervention steps are taken to minimize the risk of bankruptcy among these individuals.

The remainder of this paper will be organized as follows: Section II provides the insights from the literature followed by a discussion on the data and model in section III. Section IV presents the descriptive analysis, while section $\mathrm{V}$ discusses the empirical results. The conclusion follows in section VI.

\section{Insights from the Literature}

In the existing studies, financial vulnerability or financial fragility is indicated by an inability to maintain expenses, an inability to confront unexpected expenses, and an indebtedness or a declining real household net 

tigate how it affects consumers' retirement planning. The subjective measurement of financial literacy was added to compare what consumers actually know with what they believe they know. Thus, it is important to determine if self-confidence plays as important a role as the actual level of financial literacy.

Risk aversion is also found to play a role in consumers' financial decisions such as retirement planning (van Rooij, Lusardi \& Alessie, 2009), financial portfolio (Guiso \& Jappelli, 2009) and level of unsecured debt (Brown, Garino, \& Taylor, 2009). In the Malaysian context, there are several studies on financial strain, financial capability and in particular, financial wellbeing, of Malaysians, such as studies by Sabri, Masud, Karen, and Paim (2008), Delafrooz, Paim, Sabri, and Masud (2010) and Mokhtar, Husniyah, Sabri, and Abu Talib (2015) among others. However, there are limited studies that specifically examine the financial vulnerability of Malaysians. For example, in Sabri and Zakaria (2015), financial strain is measured in terms of individuals' emotional sentiments towards their financial situations such as their extent of worry regarding their ability to fulfill their financial commitments and regarding their availability of funds.

In this paper, in addition to considering socio-economic factors and financial knowledge to investigate the determinants of financial vulnerability among working adults in Malaysia, the model will include factors such as individuals' use of financial services and risk tolerance. The latter two factors are rarely incorporated into the models on consumer credit. Furthermore, by using two measurements of financial vulnerability that incorporate current and potential vulnerability, this paper is able to provide a more comprehensive indicator of financial vulnerability that has not been addressed in the existing studies.

\section{Data and Model}

\section{Data}

The dataset used in this study was obtained from a survey that was conducted in two locations (Penang and Klang Valley), which represent the Northern and Central commercial hubs of Peninsular Malaysia. Due to budgetary constraints, only two main commercial locations in Peninsular Malaysia were chosen, and only 900 respondents were canvassed. The two locations were also chosen because of the ease of access to financial services in these two locations. In other words, the targeted respondents were likely to be those with suitable access to financial services who were presented with various credit opportunities. The survey was conducted between January and March 2013. From the initial 900 respondents canvassed in the study, the final sample utilized responses from 854 respondents. Certain respondents were eliminated due to incomplete information. The respondents who participated in the survey are Malaysian working adults between the ages of 18 and 60 years old. A working adult is defined as an individual who works at least 30 hours a week. Convenience stratified sampling was used; the sample was stratified according to age bracket, ethnic group, and gender for both locations based on the Malaysian Labour Force Statictics of 2010 (Department of Statistics Malaysia, 2016) to reflect a better representation of the labor market in both selected locations. The respondents were solicited randomly in public places such as shopping malls, commercial areas, and offices. A face-to-face interview was conducted based on a prepared questionnaire. The data collected included information on respondents' financial status, financial knowledge, financial behavior and attitudes, and other socio-demographic characteristics.

\section{Econometric Model: Ordered Probit}

The dependent variable in this study is the level of financial vulnerability. The levels of financial vulnerability are defined as low, moderate, and high. Financial vulnerability is measured based on two indicators, debt-to-income ratio and funds sustainability in the event of income loss. For the debt-to-income ratio, an individual regarded as having a debt-toincome ratio within the recommended ratio of $30 \%$ or below will be accorded the value $=0$ or 1 otherwise (Michelangeli \& Pietrunti, 2014). Conversely, an individual who has adequate funds within the recommended level of emergency savings of at least three months or more is accorded the value 0 or 1 otherwise (Johnson \& Widdows, 1985). Summing the two indicators provides the individual's level of financial vulnerability. In other words, the values of financial vulnerability range from 0 to $2(0 \leq v \leq 2)$ , where $\mathrm{v}$ refers to the financial vulnerability score. For example, if an individual has a debt to income ra- 
tio of $30 \%$ and below but has emergency savings less than three months, the financial vulnerability score of the individual is equal to 1 , thus putting the individual at the moderate level of financial vulnerability. Conversely, if an individual has a debt to income ratio above the recommended $30 \%$ and has less than three months' emergency savings funds, the individual's financial vulnerability score is equal to 2 . Such an individual is categorized as highly vulnerable given that the individual has failed in both financial vulnerability indicators. Hence, it is clear that the dependent variable is categorical and ordinal with clear ordering. Thus, an ordered probit model is an appropriate statistical model to explain the variations in the levels of financial vulnerability among individuals (McCullaph, 1980; McKelvey \& Zavoina, 1975). In general, the ordered probit is written as follows:

$y^{*}=\beta^{\prime} x+\varepsilon$

where $y^{*}$ is the latent and continuous measure of financial vulnerability levels coded as 0,1 , or $2 ; \beta$ ' is the vector of estimated parameters, and $\mathrm{x}$ is the vector of explanatory variables; and $\varepsilon$ is the error term $\varepsilon \sim N(0,1)$ with cumulative distribution denoted by $\Phi(\bullet)$ and density function denoted by $\varphi(\bullet)$.

The observed and coded discrete financial vulnerability level, $y$, is derived from the model as follows:

$\mathrm{y}^{*}=0$ (low) if $y^{*}<\mu_{1}$

$\mathrm{y}^{\star}=1$ (moderate) if $\mu_{1}<y^{*}<\mu_{2}$

$\mathrm{y}^{*}=2$ (high) if $y^{*}>\mu_{2}$

where $\mu_{1}$ and $\mu_{2}$ are threshold variables in the probit model. The threshold variables are unknown and determine the maximum likelihood estimation procedure for the ordered probit.

\section{Variables}

The explanatory variables can be broadly categorized into socio-economic factors, risk tolerance, financial knowledge and financial sophistication.

Gender, age, ethnicity, education, income, number of dependents, and home ownership constitute the socio-economic variables, while financial knowledge includes the objective and subjective financial knowledge assessment of the individuals.

Risk tolerance is measured in accordance with Hanna, Gutter, and Fan (2001), a study in which a respondent is asked if he will leave a current job that promises a guaranteed income for life for an equally desirable job with a 50-50 chance that it will double his after-tax income or that it will reduce his income by ' $\mathrm{x} \%$ '. The respondent will be asked this question repeatedly with varying values of ' $x$ ' where $x$ begins with $5 \%$, $10 \%, 20 \%, 33 \%$, and $50 \%$. A person who is considered to have a high-risk tolerance is one who will not leave his current job if ' $\mathrm{x}$ ' is $33 \%$ or above. In other words, for other values of ' $\mathrm{x}$ ' below 33\%, a high-risk individual will choose the new job over his current job.

The financial knowledge score is derived from the financial knowledge questions posed to the respondents. The financial knowledge questions are modified and conceptualized from various financial surveys. A total of six financial knowledge questions were asked; the concepts assessed include an understanding of inflation (Atkinson, McKay, Kempson, \& Collard, 2006), interest compounding (Chen \& Volpe, 1998; Lusardi \& Tufano, 2009; Lusardi \& Mitchell, 2009), cash flow management (Credit Counseling and Debt Management Agency of Malaysia, 2011), risk diversification (Lusardi, 2008), mutual funds (Lusardi, 2008), and the recommended debt repayments in relation to the income ratio (Credit Counseling and Debt Management Agency of Malaysia, 2011). The financial knowledge score reflects the number of correct answers. In addition to the objective assessment of the individual's financial knowledge through the six financial knowledge questions, the individual is also requested to self-assess his level of financial knowledge. This request is to distinguish between the objective and subjective financial knowledge indicators. Multicollinearity between the objective and subjective indicators of financial knowledge was eliminated, because the variable inflation factor (VIF) is found to be equal to 1.04 , which is less than 10 .

Respondent's financial sophistication is measured in terms of whether the respondent diversifies his savings portfolio. A respondent who saves beyond conventional bank deposits and includes investments in stocks, mutual funds or other forms of financial instruments is considered relatively more financially sophisticated and has a diversified financial portfolio. 
Table 1. Selection of Variables

\begin{tabular}{|c|c|c|c|c|c|c|}
\hline \multirow[t]{2}{*}{ Variables } & \multirow[t]{2}{*}{ Description of Variable } & \multicolumn{3}{|c|}{ Financial vulnerability } & \multirow[t]{2}{*}{$\begin{array}{c}\text { Total } \\
\text { Sample }\end{array}$} & \multirow[t]{2}{*}{$\begin{array}{l}\text { Expected } \\
\text { signs }\end{array}$} \\
\hline & & Low & Moderate & High & & \\
\hline \multicolumn{7}{|c|}{ Binary variables ( $1=$ yes; $0=$ otherwise) } \\
\hline Gender & The respondent is a male & $\begin{array}{r}0.569 \\
(0.496)\end{array}$ & $\begin{array}{c}0.600 \\
(0.491)\end{array}$ & $\begin{array}{c}0.690 \\
(0.464)\end{array}$ & $\begin{array}{c}0.603 \\
(0.490)\end{array}$ & + \\
\hline Chinese & The respondent is Chinese & $\begin{array}{c}0.435 \\
(0.497)\end{array}$ & $\begin{array}{c}0.267 \\
(0.443)\end{array}$ & $\begin{array}{c}0.264 \\
(0.442)\end{array}$ & $\begin{array}{c}0.322 \\
(0.468)\end{array}$ & $\#$ \\
\hline Malay & The respondent is Malay & $\begin{array}{c}0.470 \\
(0.500)\end{array}$ & $\begin{array}{c}0.615 \\
(0.487)\end{array}$ & $\begin{array}{c}0.636 \\
(0.483)\end{array}$ & $\begin{array}{c}0.570 \\
(0.495)\end{array}$ & + \\
\hline Indian & The respondent is Indian or others & $\begin{array}{c}0.095 \\
(0.294)\end{array}$ & $\begin{array}{c}0.118 \\
(0.323)\end{array}$ & $\begin{array}{c}0.101 \\
(0.302)\end{array}$ & $\begin{array}{l}0.108 \\
(0.310)\end{array}$ & + \\
\hline Home & The respondent owns a house & $\begin{array}{c}0.622 \\
(0.486)\end{array}$ & $\begin{array}{c}0.443 \\
(0.497)\end{array}$ & $\begin{array}{c}0.682 \\
(0.467)\end{array}$ & $\begin{array}{c}0.539 \\
(0.499)\end{array}$ & + \\
\hline Low income & $\begin{array}{l}\text { The respondent's monthly personal } \\
\text { income is below RM1,000 }\end{array}$ & $\begin{array}{c}0.092 \\
(0.289)\end{array}$ & $\begin{array}{c}0.217 \\
(0.412)\end{array}$ & $\begin{array}{c}0.054 \\
(0.227)\end{array}$ & $\begin{array}{c}0.151 \\
(0.358)\end{array}$ & + \\
\hline Low mid income & $\begin{array}{l}\text { The respondent's monthly personal } \\
\text { income is between RM1,001 - RM4,000 }\end{array}$ & $\begin{array}{c}0.569 \\
(0.496)\end{array}$ & $\begin{array}{c}0.645 \\
(0.479)\end{array}$ & $\begin{array}{c}0.791 \\
(0.408)\end{array}$ & $\begin{array}{c}0.641 \\
(0.480)\end{array}$ & + \\
\hline High mid income & $\begin{array}{l}\text { The respondent's monthly personal } \\
\text { income is between RM4,001-RM7,000 }\end{array}$ & $\begin{array}{r}0.219 \\
(0.414)\end{array}$ & $\begin{array}{c}0.111 \\
(0.314)\end{array}$ & $\begin{array}{c}0.140 \\
(0.347)\end{array}$ & $\begin{array}{c}0.151 \\
(0.358)\end{array}$ & $\#$ \\
\hline High income & $\begin{array}{l}\text { The respondent's monthly personal } \\
\text { income is above RM7,000 }\end{array}$ & $\begin{array}{c}0.120 \\
(0.326)\end{array}$ & $\begin{array}{l}0.027 \\
(0.163)\end{array}$ & $\begin{array}{c}0.016 \\
(0.124)\end{array}$ & $\begin{array}{c}0.056 \\
(0.230)\end{array}$ & - \\
\hline Tertiary & The respondent has tertiary education & $\begin{array}{c}0.445 \\
(0.498)\end{array}$ & $\begin{array}{l}0.296 \\
(0.457)\end{array}$ & $\begin{array}{c}0.279 \\
(0.450)\end{array}$ & $\begin{array}{c}0.343 \\
(0.475)\end{array}$ & - \\
\hline Age1824 & $\begin{array}{l}\text { The respondent is aged between 18-24 } \\
\text { years old }\end{array}$ & $\begin{array}{c}0.078 \\
(0.268)\end{array}$ & $\begin{array}{l}0.170 \\
(0.376)\end{array}$ & $\begin{array}{c}0.085 \\
(0.280)\end{array}$ & $\begin{array}{c}0.126 \\
(0.333)\end{array}$ & + \\
\hline Age2529 & $\begin{array}{l}\text { The respondent is aged between } 25-29 \\
\text { years old }\end{array}$ & $\begin{array}{c}0.127 \\
(0.334)\end{array}$ & $\begin{array}{c}0.183 \\
(0.387)\end{array}$ & $\begin{array}{c}0.178 \\
(0.384)\end{array}$ & $\begin{array}{c}0.164 \\
(0.370)\end{array}$ & + \\
\hline Age 3039 & $\begin{array}{l}\text { The respondent is aged between 30-39 } \\
\text { years old }\end{array}$ & $\begin{array}{c}0.314 \\
(0.465)\end{array}$ & $\begin{array}{c}0.312 \\
(0.464)\end{array}$ & $\begin{array}{c}0.450 \\
(0.499)\end{array}$ & $\begin{array}{c}0.334 \\
(0.472)\end{array}$ & + \\
\hline Age 4049 & $\begin{array}{l}\text { The respondent is aged between } 40-49 \\
\text { years old }\end{array}$ & $\begin{array}{c}0.261 \\
(0.440)\end{array}$ & $\begin{array}{c}0.222 \\
(0.416)\end{array}$ & $\begin{array}{c}0.225 \\
(0.419)\end{array}$ & $\begin{array}{c}0.235 \\
(0.424)\end{array}$ & \# \\
\hline Age 5060 & $\begin{array}{l}\text { The respondent is aged between } 50-60 \\
\text { years old }\end{array}$ & $\begin{array}{r}0.219 \\
(0.414)\end{array}$ & $\begin{array}{c}0.113 \\
(0.317)\end{array}$ & $\begin{array}{c}0.062 \\
(0.242)\end{array}$ & $\begin{array}{c}0.141 \\
(0.348)\end{array}$ & - \\
\hline Self-knowledge & $\begin{array}{l}\text { The respondent thinks he/she has high } \\
\text { financial knowledge }\end{array}$ & $\begin{array}{c}0.230 \\
(0.421)\end{array}$ & $\begin{array}{c}0.127 \\
(0.333)\end{array}$ & $\begin{array}{c}0.140 \\
(0.348)\end{array}$ & $\begin{array}{c}0.163 \\
(0.369)\end{array}$ & - \\
\hline High risk & The respondent has high risk tolerance & $\begin{array}{c}0.102 \\
(0.304)\end{array}$ & $\begin{array}{c}0.120 \\
(0.325)\end{array}$ & $\begin{array}{c}0.171 \\
(0.378)\end{array}$ & $\begin{array}{c}0.122 \\
(0.327)\end{array}$ & + \\
\hline Finst & $\begin{array}{l}\text { The respondent diversifies his/her } \\
\text { savings portfolio }\end{array}$ & $\begin{array}{c}0.558 \\
(0.497)\end{array}$ & $\begin{array}{c}0.416 \\
(0.494)\end{array}$ & $\begin{array}{c}0.419 \\
(0.495)\end{array}$ & $\begin{array}{c}0.464 \\
(0.499)\end{array}$ & - \\
\hline
\end{tabular}

Continuous variables

\begin{tabular}{llccccc}
\hline \multirow{2}{*}{ Dependent } & Number of dependents & 2.149 & 1.980 & 2.395 & 2.098 & + \\
& & $(1.801)$ & $(1.909)$ & $(1.761)$ & $(1.856)$ & \\
Financial score & Financial knowledge score obtained & 2.707 & 2.321 & 2.450 & 2.478 & - \\
& $(\min =0 ; \max =6)$ & $(1.402)$ & $(1.385)$ & $(1.218)$ & $(1.377)$ & - \\
\hline
\end{tabular}

Note: Std. deviation in parenthesis.

\# refers to reference group 
Table 1. Selection of Variables

\begin{tabular}{|c|c|c|c|c|}
\hline \multirow[t]{2}{*}{ Variables } & \multirow[t]{2}{*}{$\begin{array}{l}\text { Coefficient } \\
\text { estimates }\end{array}$} & \multicolumn{3}{|c|}{$\begin{array}{l}\text { Marginal effects on the probabilities of financial } \\
\text { vulnerability }\end{array}$} \\
\hline & & Low & Moderate & High \\
\hline Gender & $\begin{array}{l}0.173^{* *} \\
(0.080)\end{array}$ & $\begin{array}{c}-0.049^{* *} \\
(0.023)\end{array}$ & $\begin{array}{l}0.046^{* *} \\
(0.021)\end{array}$ & $\begin{array}{l}0.036^{* *} \\
(0.036)\end{array}$ \\
\hline Malay & $\begin{array}{c}0.364^{* * *} \\
(0.094)\end{array}$ & $\begin{array}{c}-0.103^{* * *} \\
(0.032)\end{array}$ & $\begin{array}{c}0.096^{* * *} \\
(0.028)\end{array}$ & $\begin{array}{c}0.081^{* * *} \\
(0.019)\end{array}$ \\
\hline Indian & $\begin{array}{l}0.338^{* *} \\
(0.138)\end{array}$ & $\begin{array}{l}-0.096^{* *} \\
(0.041)\end{array}$ & $\begin{array}{l}0.088^{* *} \\
(0.037)\end{array}$ & $\begin{array}{l}0.072^{* *} \\
(0.054)\end{array}$ \\
\hline Dependents & $\begin{array}{l}0.049^{* *} \\
(0.023)\end{array}$ & $\begin{array}{c}-0.014^{* *} \\
(0.007)\end{array}$ & $\begin{array}{l}0.013^{* *} \\
(0.006)\end{array}$ & $\begin{array}{l}0.012^{* *} \\
(0.007)\end{array}$ \\
\hline Home & $\begin{array}{c}0.291^{* * *} \\
(0.098)\end{array}$ & $\begin{array}{c}-0.083^{* * *} \\
(0.028)\end{array}$ & $\begin{array}{c}0.076^{* * *} \\
(0.025)\end{array}$ & $\begin{array}{c}0.066^{* * *} \\
(0.023)\end{array}$ \\
\hline Low income & $\begin{array}{c}0.839^{* * *} \\
(0.248)\end{array}$ & $\begin{array}{c}-0.238^{* * *} \\
(0.040)\end{array}$ & $\begin{array}{c}0.220^{* * *} \\
(0.039)\end{array}$ & $\begin{array}{l}0.180^{* *} \\
(0.033)\end{array}$ \\
\hline Low mid income & $\begin{array}{c}0.903^{* * *} \\
(0.227)\end{array}$ & $\begin{array}{c}-0.256^{* * *} \\
(0.033)\end{array}$ & $\begin{array}{c}0.237^{* * *} \\
(0.032)\end{array}$ & $\begin{array}{c}0.190^{* *} \\
(0.029)\end{array}$ \\
\hline High mid income & $\begin{array}{c}0.647^{* * *} \\
(0.233)\end{array}$ & $\begin{array}{c}-0.184^{* * *} \\
(0.046)\end{array}$ & $\begin{array}{c}0.170^{* * *} \\
(0.044)\end{array}$ & $\begin{array}{c}0.124^{* * *} \\
(0.034)\end{array}$ \\
\hline Tertiary & $\begin{array}{c}-0.226^{* *} \\
(0.101)\end{array}$ & $\begin{array}{l}0.064^{*} \\
(0.035)\end{array}$ & $\begin{array}{c}-0.059^{*} \\
(0.031)\end{array}$ & $\begin{array}{c}-0.038^{*} \\
(0.020)\end{array}$ \\
\hline Age1824 & $\begin{array}{c}0.401^{* * *} \\
(0.148)\end{array}$ & $\begin{array}{c}-0.114^{* *} \\
(0.045)\end{array}$ & $\begin{array}{c}0.105^{* * *} \\
(0.040)\end{array}$ & $\begin{array}{c}0.085^{* * *} \\
(0.058)\end{array}$ \\
\hline Age2529 & $\begin{array}{c}0.420^{* * *} \\
(0.146)\end{array}$ & $\begin{array}{c}-0.119^{* * *} \\
(0.044)\end{array}$ & $\begin{array}{c}0.110^{* * *} \\
(0.040)\end{array}$ & $\begin{array}{c}0.098^{* * *} \\
(0.060)\end{array}$ \\
\hline Age 3039 & $\begin{array}{l}-0.121 \\
(0.110)\end{array}$ & $\begin{array}{c}-0.074^{* *} \\
(0.033)\end{array}$ & $\begin{array}{c}0.069^{* *} \\
(0.030)\end{array}$ & $\begin{array}{c}0.051^{* *} \\
(0.039)\end{array}$ \\
\hline Age 5060 & $\begin{array}{c}-0.489^{* * *} \\
(0.137)\end{array}$ & $\begin{array}{c}0.139 * * * \\
(0.053)\end{array}$ & $\begin{array}{c}-0.128^{* * *} \\
(0.046)\end{array}$ & $\begin{array}{c}-0.101^{* * *} \\
(0.037)\end{array}$ \\
\hline Financial score & $\begin{array}{c}-0.068^{* *} \\
(0.031)\end{array}$ & $\begin{array}{l}0.011^{* *} \\
(0.021)\end{array}$ & $\begin{array}{c}-0.008^{* *} \\
(0.014)\end{array}$ & $\begin{array}{c}-0.002^{* *} \\
(0.005)\end{array}$ \\
\hline Self-knowledge & $\begin{array}{c}-0.227^{*} \\
(0.117)\end{array}$ & $\begin{array}{l}0.064^{*} \\
(0.037)\end{array}$ & $\begin{array}{l}-0.059^{*} \\
(0.034)\end{array}$ & $\begin{array}{c}-0.044^{* *} \\
(0.023)\end{array}$ \\
\hline High risk & $\begin{array}{l}0.259^{* *} \\
(0.130)\end{array}$ & $\begin{array}{c}-0.007^{* *} \\
(0.039)\end{array}$ & $\begin{array}{l}0.068^{*} \\
(0.036)\end{array}$ & $\begin{array}{c}0.052^{* *} \\
(0.031)\end{array}$ \\
\hline Finst & $\begin{array}{c}-0.163^{*} \\
(0.087)\end{array}$ & $\begin{array}{l}0.046^{*} \\
(0.027)\end{array}$ & $\begin{array}{c}-0.042^{*} \\
(0.025)\end{array}$ & $\begin{array}{l}-0.034^{*} \\
(0.030)\end{array}$ \\
\hline LR stats: 121.96 (prob > chi2 $=0.000$ ) & & & & \\
\hline Pseudo R2: 0.720 & & & & \\
\hline Log-likelihood: -785.42 & & & & \\
\hline Wald test: 113.80 (prob >chi2=0.000) & & & & \\
\hline
\end{tabular}

Note: ${ }^{*}{ }^{* *}$ and ${ }^{* * *}$ denotes $10 \%, 5 \%$ and $1 \%$ significance. Robust standard error in parenthesis. 


\section{Descriptive Analysis}

Table 1 provides a summary of statistics of the survey respondents. Among the 854 respondents, the majority are moderately vulnerable financially (442; 51.7\%); 129 (15.2\%) are highly vulnerable financially, and 283 $(33.1 \%)$ are considered to have low financial vulnerability. From a cursory analysis, males are generally more financially vulnerable than females. While males comprise $60.3 \%$ of the total sample, $69 \%$ of those who are highly vulnerable are male; in addition, only $56.9 \%$ of those who have low vulnerability are males. Chinese and Malay respondents comprise $32.2 \%$ and $57 \%$ of the total sample, respectively. However, only $26.4 \%$ of those who are highly vulnerable are Chinese, while $63.6 \%$ are Malay. This finding suggests differences in the levels of financial vulnerability among different ethnic groups. Furthermore, the summary statistics show that higher income reduces financial vulnerability, whereas $33.9 \%$ of those with low financial vulnerability are of high middle income and are high income individuals; however, $79.1 \%$ of those who are highly vulnerable are from the low middle income group. The low middle income group comprise $64.1 \%$ of the total respondents in the sample. Tertiary education appears to reduce the likelihood of financial vulnerability, whereas only $27.9 \%$ of those who are highly vulnerable have tertiary education. The average knowledge score for the total sample is 2.478 ; the average knowledge score for those who are highly vulnerable (2.450) is slightly lower, while the average knowledge score for those who have low vulnerability (2.707) is slightly higher than the overall total sample's average score. Furthermore, those who have high confidence in their financial knowledge comprise $23 \%$ of those who have low financial vulnerability compared to those who have high financial vulnerability (14\%). This finding suggests that financial literacy and self-confidence in financial knowledge put individuals in a better position financially. Conversely, $17.1 \%$ of those who are highly vulnerable have a high risk tolerance, while only $10.2 \%$ of those who have low financial vulnerability have a high risk tolerance. Finally, $46.4 \%$ of the total sample's respondents diversify their savings portfolio beyond savings deposits; they comprise $55.8 \%$ of those who have low financial vulnerability, while $41.9 \%$ of those who are highly financially vulnerable diversify their savings portfolio.

\section{Results Analysis}

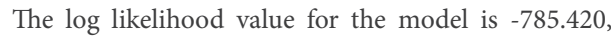
and the likelihood ratio chi-square statistic is $\mathbf{1 2 1 . 9 6}$ ( prob $>$ chi2 $=0.000$ ); however, the Wald test chi-square statistics of 113.80 (prob $>$ chi $2=0.000$ ) shows that the parameters in the model are jointly significant. Furthermore, the model has an overall predictability accuracy of $57.91 \%$. To test whether the parallel assumption is violated, an ordered probit and generalized ordered probit regression were conducted. Under the parallel assumption, it is assumed that the correlation between the independent and dependent variables do not change with the categories of the dependent variables. If the parallel assumption test fails, the generalized ordered probit model should be used instead. It was found that the ordered probit model has a lower Akaike information criterion $(\mathrm{AIC}=1582.337)$ and higher Bayesian information criterion $(\mathrm{BIC}=1753.292)$ than the generalized ordered probit model (AIC:1608.839 and BIC:1699.066). This finding suggests that the ordered probit model is an appropriate model to use.

Table 2 presents the estimates of the ordered probit (column 2) and the marginal effects of the explanatory variables on the levels of financial vulnerability (columns 3-5). The ordered probit enables the identification of significant variables that are associated with different levels of financial vulnerability. A higher coefficient estimate (column 2) indicates a higher probability of being in the highest category of financial vulnerability (high financial vulnerability), while the converse is true for a lower coefficient estimate. The effects of the changes in explanatory variables on the probability of membership in the intermediate group (moderate financial vulnerability) cannot be inferred from the estimates of the ordered probit. As such, the discussion of the empirical results focuses on the marginal effects of the explanatory variables on the respective levels of financial vulnerability.

It is found that all socio-economic factors can significantly explain the varying level of financial vulnerability among working adults. Males are more likely to be in the category of having moderate or high financial vulnerability than females. Males are more likely to be the principal loan holder for more loans than females as they are generally socialized to be the breadwinner of the family in the Asian context (Lim, Teo, \& Loo, 

fect on the level of financial vulnerability. Lusardi and Mitchell (2009) who used both objective and subjective indicators of financial knowledge also found that higher financial literacy and higher self confidence in financial knowledge increase the likelihood of retirement planning. This finding highlights the importance of financial education. Financial education will equip individuals with the basic financial knowledge and boost an individual's self-confidence in addressing financial decisions.

Holding other factors constant, an individual who has a higher risk tolerance is more likely to be financially vulnerable. The results show that an individual with a high risk tolerance has a reduced probability of having low financial vulnerability of $0.7 \%$ but has an increased probability of having high financial vulnerability of $5.2 \%$. In the existing studies on the role of risk aversion in financial decisions, it is found that those with high risk aversion have higher levels of unsecured debt (Brown et al., 2009), while Guiso and Jappelli (2009) found that those with higher risk aversion are more likely to hold risky assets and demand higher insurance coverage. Conversely, an individual who diversifies his savings portfolio beyond savings deposits is found to reduce the probability of being moderately highly vulnerable financially. Holdings of other financial instruments such as bonds and stocks appears to provide individuals with a better cushion for the availability of funds in times of emergency than those who put their savings in savings deposits only. This finding is consistent with Bhargava and Lown (2006) and Huston and Chang (1997), who found that households that are willing to take financial risks are more likely to have adequate emergency fund holdings than households that are not willing to take any financial risk.

\section{Conclusion}

This paper presents an analysis of the significance of socio-economic factors, financial knowledge, risk attitude and financial sophistication in explaining the varying levels of the financial vulnerability of working adults in Malaysia. The debt-to-income ratio and the levels of emergency savings for income shock were used to determine the overall level of financial vulnerability as the former provides the current vulnerability and the borrowing constraints of an individual, while the latter provides an indication of the potential vulnerability of the individual. In other words, the use of two measurements has provided a more holistic indicator of the financial vulnerability of an individual.

The significant age effects and ethnic differences in explaining the varying levels of financial vulnerability reflect the current bankruptcy situation in the country. Furthermore, the higher financial vulnerability of those below 40 years old are also corroborated by McCarthy's (2011) study on financial distress in the U.K and Ireland. The result that younger people tend to be more financially vulnerable is of concern as financial problems at a young age can be costly and can adversely affect an individual's lifetime financial welfare. Hence, the effort of the central bank in promoting financial education in schools and the incorporation of financial education in the school curriculum at the primary school level should be lauded and continued. As ethnicity effects are significant, a multi-lingual financial education program should be continued, and additional financial education programs could be added and expanded to target the areas with majority Malay communities. Furthermore, cultural differences could be considered and adopted to enhance the effectiveness and delivery of the financial education programs.

The financial vulnerability of low income earners requires attention. As noted by Hussein (2013), many of the low-income earners have high leverage and obtain their credit from non-bank institutions, which are outside the regulatory scope of the central bank. A "one size fits all" financial education program is clearly not suitable as the challenges confronted by low-income earners may be very different from other income groups, particularly given their lower access to financial services. Furthermore, while income poses a financial constraint on individuals, it is essential that individuals must be educated on the importance of living within their means and having a responsible financial attitude. Although the micro-prudential regulation introduced by Bank Negara Malaysia is to mitigate the issue of rising household debt, it may have made it more difficult for low income earners to gain access to credit opportunities from banking institutions. Hence, this finding is something that the authorities should examine further. 

Carvalho, M., \& Hamdan, N. (2015, June 22). Becoming bankrupt before 35 . The Star Online. Available at http://www.thestar.com.my/news/ nation/2015/06/22/becoming-bankrupt-before35 -worrying-trend-of-about-25000-gen-ymsians-in-debt-over-the-last-five-ye/

Chang, Y. R., \& Huston, S. J. (1995). Patterns of adequate household emergency fund holdings: A comparison of households in 1983 and 1986. Journal of Financial Counselling and Planning, 6, 119-128.

Chang, Y. R., Hanna, S. E., \& Fan, J. X. (1997). Emergency fund levels: Is household behaviour rational? Financial Counseling and Planning, 8(1), 47-55.

Chen, H., \& Volpe, R. P. (1998). An analysis of personal financial literacy among college student. Financial Services Review, 7(2), 107-128.

Chen, C., \& DeVaney, S. A. (2001). The effect of life cycle stages and saving motives on the probability of emergency fund adequacy. In J. M. Hogarth (Ed.), Proceedings of the Association for Financial Counseling and Planning Education (pp.176-185). Columbus, $\mathrm{OH}$ : Association of Financial Counseling and Planning Education.

Chmelar, A. (2013, May). Household debt and the European crisis (Research Report No. 13). European Credit Research Institute. Retrieved from https://www.ceps.eu/system/files/Household\%20 Debt\%20and\%20the\%20European\%20Crisis.pdf

Chow, E. (2015, September 6). Bankruptcy among the young in Malaysia crimps consumption. Reuters. Available at http://www.reuters.com/article/malaysia-economy-debt-idUSL3N10O3QR20150906

Clercq, B., van Tonder, J. A., \& van Aardt, C. J. (2015). Consumer financial vulnerability: Identifying transmission linkages that could give rise to higher levels of consumer financial vulnerability. Southern African Business Review, 19(1), 112-136.

Credit Counseling and Debt Management Agency. (2011). POWER! Managing your debts effectively. Credit Counseling and Debt Management Agency, Kuala Lumpur.

Credit Counseling and Debt Managemetn Agency [AKPK]. (2016). Lebih 700,000 dapatkan khidmat AKPK sejak 2006 [More than 700,000 has solicited services from AKPK since 2006]. Available at https://www.akpk.org.my/content/863-lebih700000-dapatkan-khidmat-akpk-sejak-2006
Department of Statistics Malaysia. (2016). Labour force survey time series data 1982-2015. Available at https://www.dosm.gov.my/v1/index. php? $r=$ column/ctimeseries\&menu_id=NHJlaGc2 Rlg4ZXlGTjh1SU1kaWY5UT09

Delafrooz, N., Paim, L. H., Sabri, M. F., \& Masud, J. (2010). Effects of financial wellness on the relationship between financial problems and workplace productivity. World Applied Sciences Journal, 10(8), 871-878.

DeVaney, S. A. (1994). The usefulness of financial ratios as predictors of household insolvency: Two perspectives. Journal of Financial Counseling and Planning, 5, 5-24.

Disney, R., Bridges, S., \& Gathergood, J. (2008). Drivers of Over-indebtedness. A Report to the Department of Business, Enterprises and Regulatory Reform. Available at http://www.nottingham. ac.uk/ lizjg1/file49248.pdf

Garman, E., \& Forgue, R. (1997). Personal Finance. Boston, MA: Houghton Mifflin Company.

Greninger, S. A., Hampton, V.L., Kitt, K. A., \& Achacoso, J. A. (1996). Ratios and benchmarks for measuring financial well-being of families and individuals. Financial Services Review, 5(1), 57-70.

Guiso, L., \& Jappelli, T. (2009). Financial literacy and portfolio diversification (Working Paper No. 212). Center for Economic Studies and Finance, Department of Economics, University of Naples. Retrieved from http://www.csef.it/WP/ wp212.pdf

Hanna, S. D., Gutter, M. S., \& Fan, J. X. (2001). A measure of risk tolerance based on economic theory. Financial Counseling and Planning, 12(2), 53-60.

Hanna, S., \& Wang, H. (1995). The adequacy of emergency funds to cover household expenditures. Consumer Interests Annual, 41, 224-225.

Hastings, J. S., \& Tejeda-Ashton, L. (2008). Financial literacy, information and demand elasticity: Survey and experimental evidence from Mexico (Working Paper No. 14538). National Bureau of Economic Research. Retrieved from http://www. nber.org/data-appendix/w14538/FinLit_Appendix_20081123.pdf

Hatcher, C. B. (2000). Should household establish emergency funds? Financial Counseling and Planning, 11(2), 77-83. 
Hilgert, M. A., Hogarth, J.M., \& Beverly, S.G. (2003, July). Household financial management: The connection between knowledge and behaviour. Federal Reserve Bulletin, 309-322.

Hung, A., Yoong, J., \& Brown, E. (2012). Empowering Women through Financial Awareness and Education (Working Paper No. 14). OECD Publishing, Paris. Retrieved from http://www.wikigender.org/ wp-content/uploads/files/EmpoweringWomenThroughFinancialAwareness.pdf

Hussein, N. (2013, April 28). Reducing the Malaysia's debt burden. East Asia Forum. Retrieved from http://www.eastasiaforum.org/2013/04/28/reducing-malaysias-debt-burden-2/

Huston, S. J., \& Chang, Y. R. (1997). Adequate emergency funds holdings and household types. Financial Counseling and Planning, 8(1), 37-46.

Jappelli, T., Pagano, M., \& Di Maggio, M. (2008, October 28). Households' indebtedness and financial fragility. Paper presented at the 9th Jacques Polak Annual Research Conference, Washington, DC. Retrieved from https://www. imf.org/external/np/res/seminars/2008/arc/ pdf/JPdM.pdf

Jappeli, T., \& Padula, M. (2011). Investment in Financial Literacy and Saving Decisions (Working Paper No. 272). Center for Studies in Economics and Finance, Department of Economics, University of Naples. Retrieved from http://www.csef.it/ WP/wp272.pdf

Johnson, D. P., \& Widdows, R. (1985). Emergency fund levels of households. In K.P. Schnittgrund (Ed.), Proceedings of the 31st Annual Conference of the American Council of Consumer Interests (pp. 235-241). Fort Worth, TX: Amer Council Consumer Interest.

Kempson, E. (2002, September). Over-indebtedness in Britain. A report to the Department of Trade and Industry. Retrieved from http://www.bristol. ac.uk/media-library/sites/geography/migrated/ documents/pfrc0203.pdf

Kimball, M. S., \& Shumway, T. (2007, January 4). Investor sophistication, and the participation, home bias, diversification, and employer stock puzzles. Retrieved from http://www-personal.umich. edu/ mkimball/keio/5.\%20papers/sophist3\%20 copy.pdf
Lim, V. K. G., Teo, T. S. H., \& Loo, G. H. (2003). Sex, financial hardships and locus of control: an empirical study of attitudes towards money among Singaporean Chinese. Personality and Individual Differences, 34(3), 411-429.

Loke, Y. J., Yen, S. T., \& Tan, A. K. G. (2013). Credit card ownership and debt status in Malaysia. Singapore Economic Review, 58(3), 17-44.

Lusardi, A., \& Mitchell, O. S. (2007). Financial literacy and retirement preparedness: Evidence and implications for financial education. Business Economics, 42(1), 35-44.

Lusardi, A. (2008). Financial literacy: An essential tool for informed consumer choice? (Working Paper No.14084). National Bureau of Economic Research. Retrieved from http://www.nber.org/ papers/w14084.pdf

Lusardi, A., \& Mitchell, O. S. (2009). How ordinary consumers make complex economic decisions: Financial literacy and retirement readiness (Working Paper No. 15350). National Bureau of Economic Research. Retrieved from http://www.nber. org/papers/w15350.pdf

Lusardi, A., \& Tufano, P. (2009). Debt literacy, financial experiences and overindebtedness (Working Paper No. 14808). National Bureau of Economic Research. Retrieved from http://www.nber.org/ papers/w14808.pdf

Malaysian Digest. (2014, February 20). Debts among us: Young Malaysians are going bankrupt. The Malaysian Digest, 20 February 2014. Available at http://www.malaysiandigest.com/ opinion/488936-debts-among-us-young-malaysians-are-going-bankrupt.html

Malaysian Digest. (2014, December 22). More Malaysians are spending well beyond their means. Available at http://www.malaysiandigest.com/ frontpage/282-main-tile/533872-more-malaysians-are-spending-well-beyond-their-means.html

McCarthy, Y. (2011). Behavioural characteristics and financial distress (Working Paper No. 1303). European Central Bank. Retrieved from https:// www.ecb.europa.eu/pub/pdf/scpwps/ecbwp1303. pdf?4ca9f70deb4b072c54015aa30aac835b

McCullaph, P. (1980). Regression models for ordinal data. Journal of the Royal Statistical Society. Series B. Methodological, 42(2), 109-142. 
McKelvey, R. D., \& Zavoina, W. (1975). A Statistical model for the analysis of ordinal level dependent variables. Journal of Mathematical Sociology, 4(1), 103-120.

Meikeng, Y. (2014, April 9). Bankruptcy cases on the rise in Malaysia. The Star Online. Available at http:// www.thestar.com.my/news/nation/2014/04/09/ bankruptcy-on-the-rise-in-malaysia/

Mian, A., \& Sufi, A. (2011, January 18). Consumer and the Economy, Part II: Household Debt and Weak U.S. Recover. Federal Reserve Bank of San Francisco, Economic Letter. Retrieved from http:// www.frbsf.org/economic-research/publications/ economic-letter/2011/january/consumers-economy-household-debt-weak-us-recovery/.

Michelangeli, V., \& Pietruni, M. (2014). A microsimulation model to evaluate Italian households' financial vulnerability (Occasional Papers No. 225). Banca D’Italia. Retrieved from https://www. bancaditalia.it/pubblicazioni/qef/2014-0225/ QEF-225.pdf

Mokhtar, N., Husniyah, A. R., Sabri M. F., \& Abu Talib, M. (2015). Financial well-being among public employees in Malaysia: A preliminary study. Asian Social Science, 11(18), 49-54.

Sabri, M. F., Masud, J., Karen, K. L., \& Paim, L. (2008). Personal financial wellness among Malaysian employees: Socio-demographic comparison. Consumer Interests Annual, 54, 189-192.

Sabri, M. F., \& Zakaria, N. F. (2015). The influence of financial literacy, money attitude, financial strain and financial capability on young employees' financial well-being. Pertanika Journal of Social Sciences and Humanities, 23(4), 827-848.

van Rooij, M., Lusardi, A., \& Alessie, R. (2007). Financial Literacy and stock market participation (Working Paper No. 146). De Nederlandsche Bank. Retrieved from https://www.dnb.nl/binaries/Working\%20Paper\%20146-2007_tcm46161161.pdf

Worthington, A. C. (2004). Emergency fund in Australian households: An empirical analysis of capacity and sources. Financial Counseling and Planning, 15(1), 21-30.

Worthington, A. C. (2005). A note on households' choice of emergency finance. Economics Bulletin, 4(5), 1-7.
Yoong, J. (2010). Financial illiteracy and stock market participation: Evidence from the RAND American Life Panel (Working Paper No. 2010-29). Pension Research Council. Retrieved from https:// ssrn.com/abstract $=1707523$

\section{Acknowledgements}

Financial support from the Research University Grant of Universiti Sains Malaysia (1001/PSOSIAL/816213) is acknowledged 